Piotr MUSIEWICZ

Akademia Ignatianum w Krakowie

piotr.musiewicz@ignatianum.edu.pl

\title{
KRYTYKA NOWEGO PRAWA O UBOGICH W UJĘCIU RUCHU OKSFORDZKIEGO (1833-1845)
}

ABSTRACT The Oxford Movement's Critique of the Poor Law Amendment Act The paper presents a short history of poor laws in England and Great Britain, the content and justifications of the Poor Law Amendment Act (1834), general characteristics of the Oxford Movement and its main political ideas, the state of contemporary research on the topic, and finally the Movement's approach to the new Poor Law. This approach - the Oxford Movement's critique - has been reconstructed into three main groups of arguments. In the first group there are arguments pointing out why a state's responsibility, and state-organised system of poor relief, is to be irrelevant and why the Church should play a far greater role in this field. The second group of arguments underlines the impracticality of centralisation in the system and proposes the major role of the local units in poor relief, as well as more 'personal' approach to the poor, also by reforming workhouses. The third group of arguments undermines the liberal (and Puritan) idea of solely individual responsibility for one's poverty and destitution - an idea underlying the new Poor Law.

Key words: the Oxford Movement, English Poor Law, Church of England, Conservatism

Słowa kluczowe: ruch oksfordzki, prawo o ubogich, Kościół anglikański, konserwatyzm 


\section{WPROWADZENIE}

Prezentacja stanowiska uczestników ruchu oksfordzkiego wobec nowego prawa o ubogich (uchwalonego w Wielkiej Brytanii w 1834 r.) poprzedzona zostanie czterema zagadnieniami wprowadzającymi, co wydaje się uzasadnione, jeśli nie konieczne, ze względów merytorycznych. Ani bowiem nowe prawo o ubogich, ani charakter i myśl ruchu oksfordzkiego nie są tematami opracowanymi w polskiej literaturze naukowej w sposób zadowalający. Zasadne będzie więc rozpoczęcie wywodu od nakreślenia historii i problematyki praw o ubogich w Anglii, specyfiki prawa o ubogich z 1834 r., charakteru i myśli przewodniej ruchu oksfordzkiego oraz stanu badań nad stosunkiem ruchu oksfordzkiego do rzeczonego prawa. Po tych zagadnieniach wprowadzających nastąpi omówienie (w trzech obszarach tematycznych) spojrzenia uczestników ruchu na nowe prawa o ubogich.

Temat niniejszego artykułu zawiera już tezę, nietrudną - jak się okaże - do udowodnienia: że stosunek ruchu oksfordzkiego do nowego prawa o ubogich był krytyczny. Głównym celem pracy pozostaje jednak udzielenie odpowiedzi na pytanie „dlaczego?”, a zatem rekonstrukcja uzasadnień i argumentacji myślicieli skupionych w ruchu oksfordzkim oraz, w konsekwencji, próba nakreślenia ich propozycji zasad społeczno-politycznych dotyczących sposobu opieki nad ubogimi.

\section{PRAWA O UBOGICH}

Problematyka praw o ubogich w Anglii i Wielkiej Brytanii to - w największej ogólności - pytania o to, kto, pod jakim warunkiem i w jaki sposób winien pomagać tym, którzy nie posiadają wystarczających środków do utrzymania się. Historycznie rzecz biorąc, wydawane w Anglii prawa i regulacje poszczególnych instytucji udzielały na te pytania różnych odpowiedzi.

W okresie przedreformacyjnym głównym sposobem zaradzania ubóstwu pozostawał „system filantropijny”, wynikający z chrześcijańskiego obowiązku troski o ubogich $^{1}$. Miał charakter niezorganizowany, to znaczy nie był uregulowany prawnie i nie istniała żadna instytucja przeznaczona wyłącznie do jego realizacji. Realizacja tego obowiązku spoczywała na wszystkich członkach społeczeństwa, w praktyce jednak najbardziej znaczącą rolę odgrywały tu klasztory, prowadzone przez nie szpitale oraz prywatna hojność zamożniejszych członków społeczeństwa. Pewnym wyjątkiem stały się regulacje: The Statut of Cambridge z 1388 r. - ustawa stanowiąca między innymi, że za „bezsilnych ubogich” (niezdolnych do pracy na skutek wieku lub niepełnosprawności) odpowiedzialne było na swoim terenie każde hrabstwo, a także The Vagabonds and Beggars Act z 1494 r. - ustawa nakładająca na żebraków obowiązek rejestracji

Zob. np. Biblia Tysiąclecia, Mt 25,32-46, Poznań 2003. 
w hrabstwie w celu zgłoszenia gotowości do podjęcia pracy, pod karą trzydniowego zakucia w dyby ${ }^{2}$.

W toku reformacji ujawniła się tendencja do większej instytucjonalizacji opieki nad ubogimi. Zadanie takie, na mocy prawa o ubogich z $1601 \mathrm{r}$. (The Act for the Relief of the Poor of 1601), zbierającego w jeden akt postanowienia szeregu poprzednich ustaw dotyczących ubogich ${ }^{3}$, otrzymał podległy władcy politycznemu Kościół anglikański. Każda poszczególna parafia została zobowiązana do dbania na swoim terenie o trzy kategorie „ubogich”. Pierwszą stanowili ci, którzy chcieli i mogli pracować, ale nie mieli takiej możliwości (otrzymywali „pomoc zewnętrzną"); drugą - bezczynni ubodzy mogący, ale nie chcący pracować (ci otrzymywali chłostę); trzecią - niezdolni do pracy na skutek wieku, choroby lub inwalidztwa (dla których przewidywano pobyt w domach pomocy) ${ }^{4}$.

Każda parafia stająca się podstawową jednostką administracyjną ,systemu opieki socjalnej" rejestrowała ubogich, zaliczając ich do którejś z powyższych kategorii. Nadzór nad organizacją pomocy sprawowali sędziowie pokoju (Justice of peace), bardziej bezpośrednio zaś zajmowali się nią nadzorcy ubogich (Overseer of the poor). Tych ostatnich, w liczbie dwóch, każda parafia (wierni) wybierała w Wielkanoc na „kadencję” jednego roku. Zadaniem nadzorców ubogich było proponowanie konkretnej pracy tym, którzy mogą pracować (odmowa przyjęcia takiej pracy wiązała się z karą), badanie wysokości potrzeb pomocy dla ubogich na terenie danej parafii, ustanawianie adekwatnej do tych celów daniny (zbieranej na niedzielnych nabożeństwach, płaconej obowiązkowo przez posiadaczy nieruchomości), dystrybucja zebranych funduszy wśród ubogich (często w postaci pożywienia i ubrania) i opieka nad parafialnymi domami pomocy (przytułki, szpitale, sierocińce, warsztaty pracy) 5 .

Ustawa z 1601 r. tworzyła w Anglii system, który - aż do roku 1834 - nie ulegał zasadniczym zmianom, lecz raczej korektom lub uszczegółowieniom. Na mocy The Settlement Act z 1662 r. uniemożliwiono wiernym samowolną zmianę parafii, do której przynależeli (praktyka taka zdarzała się, gdyż standardy opieki nad ubogimi różnily się w poszczególnych miejscach) ${ }^{6}$. Od 1723 r. (ustawa The 'workhouse test Act') rozbudowywano sieć domów pracy, do których przyjmowano często osoby potrzebujące pomocy, zamiast udzielać im wsparcia w miejscu zamieszkania ${ }^{7}$. Tendencję taką ograniczono jednak w 1782 r. - poprzez Gilbert's Act, przywracając szerszą dostępność pomocy w miejscu zamieszkania. Wprowadzony w roku 1795 system Speenhamland,

2 M. Garbat, Pauperyzacja i powstanie polityki spotecznej na przyktadzie Anglii w epoce elżbietańskiej, „Nierówności Spoleczne a Wzrost Gospodarczy” 2013, z. 34, s. 26-27.

31552 r. - ustawa o rejestracji ubogich (Law on Registration of Poor), 1563 r. - ustawa o sędziach pokoju (Justices of the Peace), 1572 r. - ustawa o daninie na ubogich (Local Poor Rate), 1576 r. - ustawa o pomocy ubogim (Poor Relief Act), 1597 r. - poprawka do ustawy o ubogich (Poor Law Amendment Act).

4 A.L. Cross, A Shorter History of England and Great Britiain, New York 1920, s. 275.

5 M. Garbat, Pauperyzacja i powstanie polityki spotecznej..., s. 29.

6 M. Bloy, The Settlement Act, [online] http://www.victorianweb.org./history/poorlaw/settle.html, 4 VII 2017.

Taż, The 'workhouse test Act', [online] http://www.victorianweb.org/history/poorlaw/testact.html, 4 VII 2017. 
umożliwiający ubogim otrzymywanie od gmin dopłat do zarobków w zależności od aktualnych cen chleba, płacy i wielkości rodzin, był rozwiązaniem przejściowym, uchwalonym w związku z kryzysem, w jakim pogrążyła się Wielka Brytania w toku wojen napoleońskich ${ }^{8}$. Ostatnie elementy tego systemu przestały obowiązywać wraz z uchwaleniem nowego prawa o ubogich.

\section{NOWE PRAWO O UBOGICH (1834 R.)}

Nie licząc okresu jednego roku (1806-1807), od 1761 do 1830 r. wszystkie brytyjskie gabinety tworzone były przez torysów. Gdy jednak w 1830 r. wybory do Izby Gmin wygrali wigowie pod przewodnictwem lorda Johna Greya (1764-1845), zwolennika polityki liberalnej, szybko przystąpili do realizacji szeregu reform społecznych i politycznych, wśród których znalazła się modyfikacja zasad udzielania pomocy ubogim

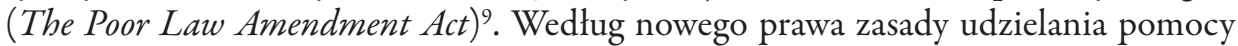
miały był jednolite i scentralizowane, aby w ten sposób zminimalizować istotne różnice lokalne i ograniczyć koszty. Na czele całego systemu stanęło trzech (centralnych) komisarzy. Parafie pogrupowano w unie (jedna unia składała się średnio z 18 parafii), które stały się podstawową jednostką administracyjną nowego systemu; do każdej unii zatrudniono jednego urzędnika za nią odpowiadającego. Aby zapanować nad wzrostem wydatków publicznych, a także aby tą drogą zachęcić ubogich do podejmowania pracy, postanowiono, że udzielana pomoc ma być na tyle nieatrakcyjna, żeby zniechęcała do korzystania z niej. Dlatego, formalnie rzecz biorąc, uwarunkowano jej udzielenie zamieszkaniem w domu pracy, którego warunki życia celowo miały być gorsze niż warunki życia najuboższych robotników (uchwalono zlikwidowanie wszelkiej pomocy w miejscu zamieszkania ubogich ${ }^{10}$ ). W celu jeszcze większego zniechęcenia do korzystania ze wsparcia rozdzielano $\mathrm{w}$ domach małżeństwa i rodziny ${ }^{11}$.

Ustawa wyrażała liberalne przekonanie, że ubóstwo i bezrobocie są oznakami deprawacji moralnej i że najlepiej przeciwdziałać im mogą (i powinni) sami ubodzy i bezrobotni. Ci, którzy korzystali z pobytu w domach pracy, mieli być uznawani za ludzi

8 M. Księżopolski, Polityka spoteczna. Wybrane problemy porównań międzynarodowych, Katowice 1999, s. 21; P. Musiewicz, Purytańska etyka pracy a ewolucja angielskiej polityki spotecznej, [w:] Wychowanie i praca. W trosce o integralny rozwój cztowieka, red. Z. Marek, J. Mółka, M. Mółka, Kraków 2017, s. 74.

9 Inne reformy podjęte wówczas przez wigów to zwłaszcza reforma prawa wyborczego na korzyść „burżuazji przemysłowej” (1832), zniesienie niewolnictwa w koloniach brytyjskich (1833), „ekonomizacyjna” reorganizacja diecezji Kościoła anglikańskiego (H. Zins, Historia Anglii, Wrocław-WarszawaKraków-Gdańsk 1979, s. 368-369; G.M. Trevelyan, Historia Anglii, przeł. A. Dębnicki, Warszawa 1963, s. 751-758).

10 Thomas Scharf wskazuje jednak, że mimo litery prawa, w praktyce świadczenia wypłacano także osobom w miejscu ich zamieszkania, bez konieczności przyjmowania ich do domów pracy (T. Scharf, Polityka spoteczna w Wielkiej Brytanii. Od ustawy o ubogich do "trzeciej drogi”, [w:] Państwo socjalne w Europie. Historia - Rozwój - Perspektywy, red. K. Kraus, T. Geisen, K. Piątek, przeł. M. Bratkowska-Zariczna, P. Zariczny, Toruń 2005, s. 62).

11 A. Llewellyn, The Decade of Reform. The 1830s, Exeter 1972, s. 105. 
dotkniętych ułomnością, niezdolnych do samodzielnego funkcjonowania. Ograniczane były ich prawa publiczne i wolności jednostkowe, tak że stawali się „obywatelami drugiej kategorii”" ${ }^{12}$. Uzasadnień dla tego prawa dostarczały koncepcje co najmniej czterech myślicieli liberalnych: anglikańskiego duchownego i ekonomisty Thomasa Malthusa (1766-1834) - wskazującego, że przyczyną ubóstwa jest zbyt liczne potomstwo współczesnych; filozofa i prawnika Jeremy'ego Benthama (1748-1832) - przekonującego, że osoby otrzymujące zorganizowaną pomoc ulegają degradacji moralnej; „klasyka ekonomii” Davida Ricardo (1772-1823) - przestrzegającego, że pomoc społeczna doprowadza do spadku płac - oraz, nieco później, ewolucjonisty Herberta Spencera (1820-1903), twierdzącego, że pomoc społeczna zakłóca naturalny proces selekcji społecznej ${ }^{13}$. Zdaniem badacza liberalizmu Lyona Blease'a, nowy system opieki nad ubogimi był nade wszystko czystym wcieleniem zasad utylitaryzmu, czyli benthamizmu ${ }^{14}$.

\section{RUCH OKSFORDZKI}

Ruch oksfordzki został zapoczątkowany w roku 1833 jako reakcja na liberalne reformy wigów. Szereg wykładowców (głównie) Uniwersytetu Oksfordzkiego, duchownych i świeckich członków Kościoła anglikańskiego, zaczęło w wykładach, publicystyce i kazaniach piętnować zapowiedzi zreformowania państwa i uniwersytetu w duchu liberalnym ${ }^{15}$. Członkowie ruchu protestowali zwłaszcza przeciwko modyfikacji anglikańskich diecezji dokonywanej przez parlament, osłabianiu znaczeniu Kościoła państwowego w życiu społecznym i politycznym, propozycjom otwarcia anglikańskich uczelni dla dysydentów (i generalnie ich równouprawnieniu społeczno-politycznemu) oraz materialistycznym trendom współczesności. Proponowali inne niż czysto erastiańskie, bo sięgające do wzorców starożytnych i średniowiecznych, ułożenie relacji państwo - Kościół, w których polityczna i społeczna rola Kościoła byłaby daleko istotniejsza niż ta, jaką widzieli dla niego liberalni wigowie ${ }^{16}$ (ruch oksfordzki zalicza się więc do nurtu konserwatywnego ${ }^{17}$ ).

12 Tamże, s. 57, 61-62; M. Garbat, Pauperyzacja i powstanie polityki spotecznej..., s. 32; P. Musiewicz, Purytańska etyka pracy..., s. 75 .

13 W.L. Blease, A Short History of English Liberalism, London 1913, s. 149, 309, 339; M. Księżopolski, Polityka spoteczna..., s. 21.

14 W.L. Blease, A Short History of English Liberalism, s. 174. W dalszej części pracy nakreślono także głębsze historycznie uzasadnienia (odwołujące się do purytanizmu) nowego prawa o ubogich.

15 Jako datę zakończenia ruchu niektórzy badacze podają rok 1845 - datę odejścia z niego jednego z przywódców, Johna Henry’ego Newmana i jego przejścia do Kościoła katolickiego, jednakże nie jest to data bezsporna ani ostateczna (zob. J.H. Overton, The Anglican Revival, London 1897, s. 120; H.P. Liddon, Life of Edward Bouverie Pusey, t. 2, London 1894, s. 217).

16 B. Szlachta, Konserwatyzm, [w:] Doktryny polityczne XIX i XX wieku, red. W. Kozub-Ciembroniewicz, K. Chojnicka, Kraków 2000, s. 133; zob. szerzej: P. Musiewicz, Krótka historia ruchu oksfordzkiego (1833-1845). O kontrowersjach traktariańskich oraz ich kontekście historycznym i religijnym, „Politeja” 2011, nr 1 (15).

17 P. Musiewicz, Ruch oksfordzki (1833-1845). Myśl polityczna przywódców ruchu oksfordzkiego, Kraków 2015, s. 153-154; Doktryny polityczne XIX i XX wieku, s. 133. 
Inne nazwy, którymi badacze określają ten ruch, to traktarianizm ${ }^{18}$ (od „traktatów" - krótkich form publicystyczno-naukowych pisanych przez jego zwolenników), puzeizm $^{19}$ (od nazwiska jednego z przywódców - Edwarda Bouverie Puseya), anglokatolicyzm ${ }^{20}$ (od profilu religijnego, jaki ostatecznie ruch przyją)).

Przywódcami ruchu, obok Puseya (1800-1882), kanonika katedralnego Oksfordu i królewskiego profesora języka hebrajskiego, oraz Johna Henry'ego Newmana (1801-1890), głównego kaznodziei uniwersyteckiego, wykładowcy w Oriel College i proboszcza w Littlemore, byli inni duchowni: John Keble (1792-1886), oksfordzki profesor poezji, kaznodzieja kościoła uniwersyteckiego i proboszcz w Hursley, oraz Richard Hurrell Froude (1803-1836) - wykładowca w Oriel College. Obok przywódców do grona uczestników ruchu oksfordzkiego zalicza się co najmniej kilkadziesiąt innych osób, spośród których w niniejszym artykule przywoływane będą wypowiedzi o nowym prawie o ubogich zwłaszcza prawnika i publicysty Samuela Bosanqueta (1800-1882), wykładowcy i kapelana Balliol College Fredericka Oakeleya (1802-1880) ${ }^{21}$, proboszcza w Cholderton i redaktora „British Critic” Thomasa Mozleya (1806-1893) oraz proboszcza w Elford, autora powieści Francisa Pageta (1806-1882).

Nim ukazane zostanie spojrzenie ruchu oksfordzkiego na nowe prawo o ubogich, trzeba zaznaczyć, że jego uczestnicy traktowali angielskie społeczeństwo jako chrześcijańskie (choć ulegające laicyzacji między innymi ze względu na posunięcia polityczne partii wigowskiej fundującej rozwiązania społeczno-polityczne na gruncie świeckiej ekonomii ${ }^{22}$. Społeczeństwo takie miało czerpać zasady polityczne z Objawienia i nauki Kościoła anglikańskiego. Traktarianie nie byli zwolennikami rozdziału Kościoła od państwa, twierdząc, że straciłoby na tym przede wszystkim państwo (a w konsekwencji społeczeństwo), pozbawione odpowiednich standardów postępowania ${ }^{23}$; rozdział taki skłonni byli rozważać jedynie w sytuacji, gdyby polityka złączonego z Kościołem państwa uniemożliwiała realizację funkcji, powołania Kościoła ${ }^{24}$. Odwołując się do twórcy

18 H. Newland, Three Lectures on Tractarianism, London 1852.

19 O ruchu religijnym w Anglii, „Przegląd Poznański” 1845, t. 2, s. 285-286.

20 W. Gresley, Anglo-Catholicism, A Short Treatise on the Theory of the English Church, London 1844; J.H. Newman, Apologia pro vita sua, London 1903, s. 68. Anglokatolicyzm ma jednak pojęcie szersze niż ruch oksfordzki, gdyż de facto wyrósł on z tego ruchu i trwa do dziś (Ch. Dawson, The Spirit of the Oxford Movement, London 2011, s. 1).

21 Oakeley podążył drogą Newmana i w 1845 r. przeszedł do Kościoła katolickiego.

22 Zob. np. J. Keble, National Apostasy Considered. In a Sermon Preached in St. Mary, Oxford, before His Majesty's Judges of Assize, on Sunday, July 14, 1833, Oxford 1833.

23 H.J. Laski, Studies in the Problem of Sovereignty, New Haven 1913, s. 83, 87. Pusey twierdził, że rozdział Kościoła od państwa pociągnie za sobą między innymi brak szacunku władz politycznych i sprzyjać będzie wystąpieniom i buntom przeciw nim; z tego powodu rozdział ten nazywał samobójstwem dla panstwa (E.B. Pusey, The Royal Supremacy. Not an Arbitrary Authority but Limited by the Laws of the Church of which Kings are Members, Oxford 1850, s. 208-209).

24 R.H. Froude, Remains of the Late Reverend Richard Hurrell Froude, vol. 3, red. J.H. Newman, J. Keble, J.B. Mozley, London 1839, s. 274; A Collection of Papers Connected with the Theological Movement of 1833, red. A.P. Perceval, London 1842, s. 12; J.R. Griffin, John Keble: Radical, „Anglican Theological Review" 1971, vol. 53, s. 172. 
teoretycznej podstawy jedności państwa i Kościoła anglikańskiego, Richarda Hookera $(1554-1600)^{25}$, prowadzili refleksję, biorąc za punkt wyjścia tę właśnie jedność. Te wstępne uwagi powinny pomóc we wprowadzeniu w charakter argumentacji ruchu oksfordzkiego wobec nowego prawa o ubogich, argumentacji sięgającej w pewnej mierze do przesłanek zupełnie „niereligijnych”, ale także do Objawienia, zasad Kościoła i jego historii. Pozwolą też zrozumieć, że chociaż kwestia reformy prawa o ubogich nie stanowiła bezpośredniego impulsu do zawiązania ruchu, ani też głównego obiektu krytyki podejmowanej przez jego uczestników, to jednak argumenty przywoływane w tej krytyce okażą się bardzo głębokie i związane ze sprawami fundamentalnymi dla ustroju państwa, takimi jak społeczno-polityczna rola państwa i Kościoła oraz charakter związku między nimi.

\section{ZARYS STANU BADAŃ NAD STOSUNKIEM RUCHU OKSFORDZKIEGO DO NOWEGO PRAWA UBOGICH (1834 R.)}

Chociaż w literaturze anglosaskiej problematyce nowego prawa o ubogich oraz stosunku do niego różnych grup społecznych i politycznych poświęcono już sporo miejsca, nie powstało dotąd opracowanie poświęcone stosunkowi do niego ruchu oksfordzkiego. Historyk Simon Skinner zauważa, że istniejące opracowania prezentujące myśl oponentów tego prawa (np. czartystów ${ }^{26}$ ) rzadko wspominają o krytyce wychodzącej ze środowisk Kościoła anglikańskiego lub grup dysydenckich, a jeśli już to czynią, prezentują ją w sposób wycinkowy, pozbawiający ją rzeczywistych uzasadnieńn ${ }^{27}$. Istotnie, o takiej krytyce nie wspomniał historyk Norman McCord ${ }^{28}$; inny badacz, John Knott, chociaż stwierdził, że przekonania religijne dostarczyły krytykom nowego prawa istotnej argumentacji, sugerował, że argumentację taką podejmował jedynie ruch metodystyczny ${ }^{29}$; Nicholas C. Edsall wspominał o opozycji z kręgów Kościoła anglikańskiego, ograniczył ją jednak do poszczególnych parafii i - podobnie jak Knott - konkludował, że wiodący sprzeciw wobec reformy spośród „kręgów kościelnych” pochodził od nonkonformistów ${ }^{30}$. Jeszcze inni, jak Edward Norman, sugerują, że sprzeciw wychodzący ze środowiska Kościoła anglikańskiego był bardzo krótkotrwały i nieznaczący, skoro pryncypia reformy, zwłaszcza zasada tzw. ekonomii politycznej, miały zostać szybko

25 P. Musiewicz, Ruch oksfordzki (1833-1845)..., s. 93-102; zob. także: R. Hooker, The Works of that Learned and Judicious Divine, Mr. Richard Hooer. With an Account of His Life and Death by Isaac Walton, vol. 1, red. J. Keble, New York 1845, s. vi-lii.

26 H. Zins, Historia Anglii, s. 370-371.

27 S.A. Skinner, Tractarians and the 'Condition of England'. The Social and the Political Thought of the Oxford Movement, Oxford 2004, s. 236.

28 N. McCord, The Poor Law and Philanthropy, [w:] The New Poor Law in the Nineteenth Century, red. D. Fraser, London 1976, s. 87-100.

29 J. Knott, Popular Opposition to the 1834 Poor Law, London 1986, s. 247-252.

30 N.C. Edsall, The Anti-Poor Law Movement, 1834-44, Manchester 1971, s. 63. 
(kilkanaście lat po uchwaleniu prawa) przyjęte przez kler parafialny ${ }^{31}$. W większym stopniu odwołania do religii wśród krytyków prawa ubogich dostrzegł John T. Ward, skoncentrował się jednak na prezentacji argumentów George’a Stringera Bulla ${ }^{32}$ i Richarda Oastlera ${ }^{33}$ - nie wspominając w ogóle o ruchu oksfordzkim ${ }^{34}$. Wreszcie generalnie bardzo rzetelna praca Felixa Drivera redukuje zastrzeżenia środowisk Kościoła anglikańskiego do nowego prawa o ubogich do wspomnienia ledwie, że podnosily one sprzeciw wobec centralizacji oraz wskazywały na niezgodność z tradycjami angielskiego życia lokalnego i jego "moralną ekonomią" ${ }^{35}$. Podobnie zsekularyzowany obraz oporu przeciw nowym prawom o ubogich namalował John Belchem ${ }^{36}$, a Thomas Scharf przy opisie nowego prawa o ubogich w ogóle nie użył terminu „parafia” ${ }^{\text {"7 }}$. Trudno oprzeć się wrażeniu, że powyższe ujęcia problemu nie zawsze zmierzają do odtworzenia rzeczywistej argumentacji anglikańskich krytyków nowego prawa o ubogich. Jej przedstawienie - w odniesieniu do reprezentantów ruchu oksfordzkiego - pozostaje właśnie celem niniejszego artykułu.

\section{POMOC DLA UBOGICH - KOŚCIÓŁ CZY PAŃSTWO?}

Pierwsza grupa argumentów, przytaczanych przez uczestników ruchu oksfordzkiego, wiązała się generalnie z krytyką dużego zaangażowania państwa w pomoc ubogim. Zaangażowanie to niosło ze sobą, ich zdaniem, negatywne konsekwencje społeczne. Pomijając na razie kwestie praktyczne (czy pomoc organizowana przez państwo rzeczywiście zaradzała problemowi ubóstwa), trzeba stwierdzić, że traktarianie krytycznie odnosili się do samej zasady organizowania i realizowania systemu pomocy społecznej przez władze państwowe.

Było to spowodowane dostrzeganiem przez ruch oksfordzki faktu, że pomoc społeczna organizowana przez państwo ma zwykle, a już na pewno w systemie nowego prawa o ubogich, charakter przymusowy. Na drodze ustawowej wprowadzony zostaje

31 E.R. Norman, Church and Society in England 1770-1970. A Historical Study, Oxford 1976, s. 123.

32 George Stringer Bull (1799-1865) - anglikański duchowny o poglądach ewangelikalnych, oddany pracy duszpasterskiej w przemysłowych rejonach Anglii (Birmingham). Postulował między innymi zniesienie niewolnictwa, ograniczenie czasu pracy robotników, zwłaszcza dzieci, do dziesięciu godzin dziennie (zob. J.C. Gill, Parson Bull of Byerley. A biography of George Stringer Bull, London 1963).

33 Richard Oastler (1789-1861) - angielski publicysta o poglądach metodystycznych i torysowskich, postulujący zniesienie niewolnictwa i ograniczenie czasu pracy robotników. Zdecydowanie występował przeciw nowemu prawu o ubogich, zachęcając do tego niektórych członków parlamentu. Nowe prawo miało przyczynić się do spadku pensji dla robotników, pogorszenia ich warunków pracy i pogłębienia przepaści między pracodawcami a pracownikami (zob. C. Driver, Tory Radical. The Life of Richard Oastler, Oxford 1946; W.L. Blease, A Shorter History of English Liberalism, s. 177).

34 J.T. Ward, The Factory Movement 1830-1855, London 1962, s. 158-178.

35 F. Driver, Power and Pauperism. The Workhouse System, 1834-1884, Cambridge 1993, s. 114.

36 J. Belchem, Industrialization and the Working Class. The English Experience, 1750-1900, Aldershot 1990, s. 101-104.

37 T. Scharf, Polityka spoteczna w Wielkiej Brytanii..., s. 61-62. 
bowiem przymusowy podatek, z którego wpływy przeznaczone są na wsparcie dla potrzebujących, a to zaś sprawia, że zanika dobrowolność pomocy, którą bardzo wysoko cenili. Jak pisał Oakeley: Jeden akt niewymuszonej wspaniatomyślności znaczy więcej niż tysiąc czynów podjętych z przymusu ${ }^{38}$. Uczestnicy ruchu oksfordzkiego, rozpatrując problem opieki nad ubogimi, brali pod uwagę nie tyle, jak wigowie, zasady „politycznej ekonomii" ${ }^{39}$, ile osobiste motywacje udzielających pomocy. Wynikało to z ich chrześcijańskiego etosu, przywołującego także zasady przedreformacyjne. Komentując Ewangelię Mateusza 25,35-40 ${ }^{40}$, Pusey stwierdzał, że dawanie ubogim z powodu przymusu państwowego nie wypełnia ewangelicznego przykazania pomocy, które można należycie spełnić tylko w drodze osobistego, dobrowolnego daru ${ }^{41}$. Bosanquet przekonywał, że nowe prawo oparte na ekonomii sprzeciwia się biblijnemu obowiązkowi osobistej szczodrości ${ }^{42}$. Wsparcie ubogich, w ujęciu ruchu oksfordzkiego, pozostaje zatem obowiązkiem społecznym, lecz nie takim, który należałoby realizować na drodze egzekucji prawa czy restrykcji ${ }^{43}$. Ma ono nie tylko wymiar doczesny, ale - ważniejszy w ich odczuciu - duchowy, któremu powinno służyć ustawodawstwo państwa pozostającego w związku z Kościołem ${ }^{44}$.

38 F. Oakeley, Remarks on the Study of Aristotelian and Platonic Ethics, as a Branch of the Oxford System of Education, Oxford-London 1837, s. 83.

39 „Polityczna ekonomia” jest terminem używanym przez traktarian, najczęściej przez Samuela Bosanqueta, stosowanym zamiennie z terminami „utylitaryzm” i „benthamizm”. Wszystkie uważali za zasady ptytkie, zarozumiate, powodujące ekskluzywność i tyranię; znaczyły one dla nich zdobywanie pieniędzy [...] nie dbając o to, że ubodzy umierają na ulicach [...] oraz wojnę z ubogimi, gdyż ekonomicznym pozostawato okazywać wsparcie jedynie tym, którzy dowieść mogli, że gtodują bez żadnej wtasnej winy oraz nie z powodu żadnej wtasnej stabości (S. Bosanquet, Pauperism and Alms-giving, „British Critic” 1840, vol. 28, nr 55, s. 207, 227). Wymyśliliśmy dla samych siebie sterylne maksymy ekonomiczne po to, aby bogaci mogli usprawiedliwiać odwracanie się od biednych (W. Gresley, Acceptable Sacrifice. A Sermon Preached in St. John's Church, Cheltenham, London-Cheltenham 1843, s. 15). Inna definicja „politycznej ekonomii” (w ujęciu Newmana) oznaczałaby, że liczą się jedynie efekty działań, a pomijany jest cały obszar ludzkiej moralności i motywacji (zob. P. Musiewicz, Ruch oksfordzki (1833-1845)..., s. 269).

40 Wtedy odezwie się Król do tych po prawej stronie: „Pójdźcie, btogostawieni Ojca mojego, weźcie w posiadanie królestwo, przygotowane wam od zatożenia świata! Bo bytem gtodny, a daliście Mi jeść; bytem spragniony, a daliście Mi pić; bytem przybyszem, a przyjęliście Mnie; bytem nagi, a przyodzialiście Mnie; bytem chory, a odwiedziliście Mnie; bytem w więzieniu, a przyszliście do Mnie”. Wówczas zapytaja sprawiedliwi: „Panie, kiedy widzieliśmy Cię gtodnym i nakarmiliśmy Ciebie? spragnionym i daliśmy Ci pić? Kiedy widzieliśmy Cię przybyszem i przyjęliśmy Cię? lub nagim i przyodzialiśmy Cię? Kiedy widzieliśmy Cięchorym lub w więzieniu i przyszliśmy do Ciebie?”. A Król im odpowie: „Zaprawde, powiadam wam: Wszystko, co uczyniliście jednemu z tych braci moich najmniejszych, Mnieście uczynili" (Biblia Tysiąclecia, Poznań 2003).

${ }_{41}$ E.B. Pusey, Christianity without the Cross a Corruption of the Gospel of Christ. A Sermon Preached before the University of Oxford on Septuagesima Sunday, Oxford-London 1875, s. 27-28.

42 Otwórz szczodrze rękę swemu bratu uciśnionemu lub ubogiemu w twej ziemi (Pwt 15,11). Zob. S. Bosanquet, Pauperism and Alms-giving, s. 242.

43 E.B. Pusey, Parochial Sermons, 1848-1883, vol. 3, Oxford-London 1886, s. 143.

44 Tenże, Patience and Confidence the Strength if the Church. A Sermon Preached on the Fifth of November before the University of Oxford at S. Mary's, Oxford 1841, s. 26. Wydaje się, że w tym ujęciu władza świecka mogła być raczej środkiem do realizacji „celu religijnego” niż podmiotem mogącym go określać (P. Musiewicz, Ruch oksfordzki (1833-1845)..., s. 81). 
Traktarianie twierdzili, że zaangażowanie państwa w pomoc ubogim poprzez zbieranie podatku przeznaczonego na ten cel przerzuca niejako w świadomości członków społeczeństwa odpowiedzialność za opiekę z jednostek na system państwowy, co utrudnia realizację religijnego obowiązku. Ponadto zastąpienie obowiązku osobistej pomocy charytatywnej systemem publicznym ma wzmagać chciwość lepiej uposażonych, posiadających, co w konsekwencji pogłębia podział społeczny między klasami niższymi a zamożniejszymi. Twierdzili, że za ustawą wigów o pomocy społecznej kryje się w istocie przekonanie, że winna ona mieć jedynie charakter publiczny, najlepiej państwowy, i że wszelkie osobiste, dobrowolne formy pomocy ubogim są przez twórców reformy piętnowane (ci, którzy bezpośrednio przekazują pomoc ubogim - przekonywali traktarianie - są wręcz traktowani jako dopuszczający się występku $)^{45}$.

Inny negatywny aspekt zaangażowania państwa w pomoc dla ubogich wiązał się, według traktarian, $\mathrm{z}$ ideą ekonomizacji wpisaną w nowe prawo o ubogich. Skoro pomoc stała się podatkiem, może być, i zapewne będzie, poddawana ekonomizacji. Ekonomizacja, jakiej obawiali się traktarianie, polegała na dostosowywaniu jej zakresu do abstrakcyjnie przyjmowanych zasad i wielkości, co w praktyce prowadzić miało do ograniczania wysokości pomocy i uniknięcia rzeczywistego rozwiązania problemu ${ }^{46}$. Ekonomizacja taka miała być „cnotą” klasy średniej i służyć w istocie jej interesom, tzn. zmniejszać i tak stosunkowo niewielkie jej obowiązki względem ubogich i sprzyjać rozwojowi indywidualizmu ${ }^{47}$. Dodatkowo, skoro wysokość tej pomocy jest zmienna i ustalana przez władze polityczne, zasada ekonomizacji stoi w sprzeczności z zasadą pomocy dla ubogich znajdowaną w Objawieniu i nauczaną przez Kościół (przynajmniej anglikański), że wierni zobowiązani są przeznaczać na potrzebujących dziesiątą część swoich dochodów ${ }^{48}$.

Argumenty te ujawniają głębsze przekonanie, żywione przez uczestników ruchu oksfordzkiego, że pomocą dla ubogich winien zajmować się Kościół i że próby przejęcia tego obowiązku przez państwo stanowią uzurpację ${ }^{49}$. Państwo nie powinno samodzielnie, bez Kościoła, określać obszarów przez siebie regulowanych, jako że ze swej natury nie jest niezależne od Kościoła. Keble twierdził, że jedność Kościoła i państwa nie dokonała się na zasadzie unii dwóch równorzędnych partnerów, lecz na zasadzie inkorporacji - przystąpienia państwa do Kościoła. W układzie tym (a także poza nim) Kościół jest rzeczywistością pierwotniejszą i umocowaną bezpośrednio przez Boga, jego

45 S. Bosanquet, Pauperism and Alms-giving, s. 203.

46 Znacznie tatwiej jest siedzieć w domu, czytajac sprawozdania, raporty, dowody, liczby, statystyki, i proponować rozwiązania problemów spotecznych za pomoca tabelek i dziatań zgodnych matematycznie [...] niż udawać się na brudne dziedzińce, do ciasnych pokoi i piwnic petnych robactwa, kurzu i zarazków, aby rozmawiać z tamtejszymi ludźmi z nizin, wulgarnymi, umierajacymi, nietrzeźwymi, nieszczęśliwymi (tamże, s. 201-202).

47 Tenże, Private Alms and Poor-law Relief, „British Critic” 1840, vol. 28, nr 56, s. 449.

48 Tamże, s. 456; tenże, The Age of Unbelief, „British Critic” 1842, vol. 31, nr 61, s. 119. Zob. też: Biblia Tysiaclecia, Kpł 27,30; Lb 18,26; Pwt 14,24; 2 Krn 31,5; 1 Kor 16,1-2.

49 S.A. Skinner, Tractarians and the 'Condition of England'..., s. 222; S. Bosanquet, Private Alms and Poor-law Relief, s. 441. 
funkcje są więc bardziej pierwotne niż funkcje państwa ${ }^{50}$. Dlatego też Kościół nie może być pomijany przy podejmowaniu decyzji politycznych, w tym decyzji dotyczących prawa o ubogich ${ }^{51}$. Sprawami ubogich zajmował się on wcześniej niż państwo i czynił to z nakazu Bożego. Przy podejmowaniu decyzji tego rodzaju jego głos powinien być uwzględniony (traktarianin William George Ward wskazywał nawet, że zadaniem Kościoła jest zarówno zajmowanie się sferą duchową, jak i dostarczanie państwu podstawowych zasad dotyczących organizacji sfery temporalnej ${ }^{52}$ ).

Wydaje się, że oczekiwania ruchu oksfordzkiego co do właściwej pozycji władzy politycznej w pomocy biednym były spełnione w elżbietańskiej Anglii. Pierwsze prawo o ubogich (1601 r.) generalnie powierzało odpowiedzialność za system opieki nad ubogimi Kościołowi, konkretniej parafiom anglikańskim, nadzorowanym jedynie przez sędziów pokoju, którzy zresztą musieli być członkami tegoż Kościoła. Było ono na tyle ogólne, że faktycznie pozostawiało poszczególnym jednostkom parafialnym istotną swobodę działania. Nie zostało też uchwalone wbrew stanowisku konwokacji, ani też przez parlament, który zdecydowany byłby zmniejszyć wpływ Kościoła w sferze publicznej (w przeciwieństwie do parlamentu „wigowskiego” z 1830 r.). W przypadku tego prawa władca świecki nie wkraczał w sferę zastrzeżoną dla Kościoła ${ }^{53}$, lecz pozostawiał mu realizację obowiązku opieki nad ubogimi.

\section{CENTRALIZACJA I „DEPERSONALIZACJA” POMOCY}

Drugi obszar krytyki nowego prawa o ubogich można by nazwać „personalistycznym”, gdyż wyrażał on troskę o osobisty charakter i jakość otrzymywanej pomocy. W obszarze tym uczestnicy ruchu oksfordzkiego zwracali uwagę, że pomocą dla ubogich administrują instytucje zbyt centralne - odległe od spraw lokalnych, że warunki udzielania pomocy są nazbyt jednolite - nieróżnicujące poszczególnych sytuacji - i że otrzymywana pomoc ma właściwie charakter bezosobowy.

50 J. Keble, Church and State, [w:] tegoż, Sermons Academical and Occasional, Oxford 1848, s. 57; tenże, The State in its Relations with the Church, Oxford 1869 (przedruk z „British Critic” 1839), s. 7; P. Musiewicz, The Oxford Movement's Arguments for the Union of Church and State, „Horyzonty Polityki” 2014, vol. 5, nr 13, s. 118; S.A. Skinner, Tractarians and the 'Condition of England'..., s. 102.

51 Przez pomijanie Kościoła uczestnicy ruchu oksfordzkiego rozumieli przede wszystkim nieodwoływanie się władz państwowych do ustaleń konwokacji oraz zawieszenie (w 1717 r.) praktyki zwoływania konwokacji (którą od czasów reformacji zwoływał władca polityczny), będącej, w ich odczuciu, swoistym parlamentem Kościoła anglikańskiego (zob. J.H. Newman, Convocation of Canterbury, [w:] tegoż, Historical Sketches, vol. 3, London 1909, s. 341-342).

52 W.G. Ward, The Ideal of a Christian Church, London 1844, s. 48. Model taki miał zostać zrealizowany w starożytności chrześcijańskiej, kiedy cesarze rzymscy wydawali prawa bazujące na doktrynie chrześcijańskiej - np. zakaz rozwodów, uczynienie niedzieli dniem wolnym od pracy czy delegalizacja innych niż nicejskie wyznań wiary (zob. E.B. Pusey, The Royal Supremacy, s. 26-27; I. Ker, John Henry Newman, Oxford 2009, s. 66).

53 J.H. Newman, Convocation of Canterbury, s. 416. 
Unie parafii, stanowiące podstawową jednostkę administracyjną nowego systemu, według traktarian nie były w stanie rozpoznać rzeczywistych potrzeb ubogich, a przez to dostarczyć im adekwatnej pomocy. Umocowanie głównej odpowiedzialności za ubogich na danym obszarze w urzędnikach oraz w centralnych komisarzach miało sprawiać, że administrujący tym systemem podejmowali decyzje o konkretnej pomocy bez osobistej znajomości sytuacji ubogich. Dlatego uczestnicy ruchu oksfordzkiego proponowali, aby urzędnicy i komisarze, zamiast zarządzać systemem, stali się doradcami parafii, bezpośrednio komunikującymi się z osobami odpowiedzialnymi za pomoc w parafiach (proboszcz i nadzorcy). Urzędnicy ci mieliby jedynie służyć pomocą parafiom, a zarazem sprzyjać dążeniom do rozbudowy dobrowolnego systemu pomocy ubogim i redukcji przymusowego. To oczywiście oznaczało, że traktarianie pragnęli porzucenia centralizacji i przywrócenia parafiom głównej odpowiedzialności za pomoc ubogim ${ }^{54}$.

Konsekwencją scentralizowania pomocy stała się jednolitość zasad jej udzielania, która miała przynosić niesprawiedliwość. W ten sam sposób traktowano bowiem kalekich, chromych, ślepych, sparaliżowanych [...], co żebraków, pijaków, rozpustników - na takich samych zasadach przyjmowano ich do domów pracy ${ }^{55}$. Zasady te same w sobie, jak diagnozowali traktarianie, były poniżające i nieracjonalne. Stanowiły, że do domów pracy przyjmowani są jedynie najubożsi z ubogich - jedynie ci, którzy nic nie maja [...], a więc mechanik, którego rodzina gtoduje i który jednak ma prace, musi sprzedać swe narzędzia, aby otrzymać pomoc. Kto inny, powalony choroba, lub ktoś, kto utracit swe dobra, musi rozstać się z catą swą chata. Woźnica, którego koń zginąt w wypadku, musi sprzedać swój wóz i zejść na najniższy poziom ubóstwa ${ }^{56}$.

W systemie nowego prawa o ubogich brakowało też osobistego kontaktu i rozmowy z potrzebującymi, dzięki którym dokładniej można by zaznajomić się z sytuacją danego ubogiego i jego warunkami życia. Rozmowy takie, twierdzili uczestnicy ruchu, można przeprowadzać jedynie w małych jednostkach, jakimi są parafie, nie zaś w ich uniach. Konkretniej pozwoliłoby to na odejście od systemu pomocy przyjmowania do domów pracy na rzecz zwiększenia (przywrócenia) pomocy w miejscu zamieszkania, która byłaby dzięki temu adekwatniejsza do danej sytuacji, nie zaś przydzielana na podstawie abstrakcyjnych kryteriów ${ }^{57}$.

„Depersonalizujący” charakter miały też trudne warunki domów pracy, pozostających formalnie jedynym sposobem pomocy dla ubogich. Thomas Mozley nazywał je haniebnymi, twierdził, że słusznie ubodzy nazywają je bastyliami (w których wigowie mają umieszczać więźniów niczym trędowatych), i przyrównywał pobyt w nich do wrzucania żywcem do grobów $w^{58}$. Jako proboszcz przestrzegał swoich parafian, aby

\footnotetext{
54 S. Bosanquet, Private Alms and Poor-law Relief, s. 456-457.

55 Tamże, s. 449.

56 Tamże, s. 445, 448.

57 Tamże, s. 456-457.

58 T. Mozley, Armed Associations for the Protection of Life and Property, „British Critic” 1839, vol. 26, nr 52, s. 427; tenże, Pews, „British Critic” 1842, vol. 32, nr 64, s. 489.
} 
nie udawali się do tych domów, wspominając przy tym, że ci, którzy tam zamieszkali, nie żyli długo ${ }^{59}$.

W powieściach Francisa Pageta pojawiają się okrutne postacie dyrektorów domów pracy, jak Mr Venham, który dotkliwie pobił jedną z bohaterek powieści, będącej rezydentką domu, za rozbicie dwóch talerzy (brat bohaterki nie wytrzymał zaś warunków domu i popełnił samobójstwo), czy Mr Clemmalive, który przeznaczał dla rezydentów jednolitą „dietę”, na którą składała się jedynie woda ${ }^{60}$. Obserwacja doświadczeń z domów pracy prowadziła go do stwierdzenia, że żaden inny naród nie ma tak zatwardziatego serca, aby pozwolić choćby przez godzinę funkcjonować takiemu prawu, jak prawo ubogich w swym obecnym ksztatcie ${ }^{61}$.

„Odtrutką” na tę nieludzką pomoc miało być przywrócenie kościelnego systemu pomocy. Pod jego auspicjami, twierdzili uczestnicy ruchu, nawet domy pracy mogły zostać „odkupione” - przemienione na domy ubogich, na miejsca schronienia, w których rzeczywiście zaradza się nieszczęściu i nędzy ${ }^{62}$.

\section{UBÓSTWO A UPADEK MORALNY}

Twórcy reformy prawa o ubogich, uzasadniając ją, powoływali się nie tylko na racje ekonomiczne i organizacyjne, ale też filozoficzno-moralne. W szczególności przywoływali przekonanie, że przyczyną indywidualnego ubóstwa pozostają nie tyle okoliczności społeczne, ile upadek moralny poszczególnych jednostek. Z tego powodu - twierdzili - dostarczenie ubogim pomocy zda się na nic, skoro nie wyprowadzi ich z upadku, a spowoduje jedynie niezasadne obciążenia finansowe innych. Znacznie lepszym sposobem na zaradzenie temu upadkowi miało być „zmotywowanie” ubogich do weryfikacji własnej postawy, do podniesienia standardów moralnych, a w efekcie - do znalezienia i podjęcia pracy, która stałaby się faktycznym źródłem utrzymania danego ubogiego i jego rodziny. „Motywowanie” to miało się dokonywać poprzez perspektywę zamieszkania w domu pracy, mającej być jedyną (odstraszającą) alternatywą dla samodzielnego zarabiania na własne utrzymanie poprzez pracę ${ }^{63}$.

Optyka taka była wyrazem dziewiętnastowiecznych poglądów liberalnych, zwłaszcza angielskich, które, jak się wydaje, rozwinęły się jako zsekularyzowane przekonania purytańskie ${ }^{64}$.

59 Miał on na myśli zwłaszcza konkretny dom pracy - Andover Union; zob. T. Mozley, Reminiscenses, Chiefly of Oriel College and the Oxford Movement, vol. 2, London 1882, s. 172.

60 F.E. Paget, Warden of Berkingholt, Oxford 1843, s. 119-120; tenże, Milford Malvoism or Pews and Pewholders, London 1842, s. 181.

61 Tenże, The Pageant, London 1843, s. 68.

62 S. Bosanquet, Private Alms and Poor-law Relief, s. 456-457.

63 A. Pratt, Subsydiowanie ptac, polityka spoteczna i państwo. Od prawa o ubogich do polityki „nowej” partii pracy, [w:] Polityka spoteczna. Teorie, pojęcia problemy, red. M. Lavalette, A. Pratt, przeł. P. Jaworski, Warszawa 2010, s. 329-331.

64 M. Goldie, Priestcraft and the birth of Whiggism, [w:] Political Discourse in Early Modern Britain, 
Purytanie podkreślali, że praca jest obowiązkiem nałożonym na wszystkich ludzi przez Boga, że pozostaje celem duchowym prowadzącym też do zabezpieczenia, a nawet dobrobytu materialnego. Obowiązkiem było podejmowanie takiej pracy, która przynosiłaby odpowiednie dochody. W związku z tym kanonizacji uległy cechy związane z przedsiębiorczością. Chciwość przestała być ciężkim grzechem, a na czoło czarnej listy wysunęło się lenistwo i bezczynność, które właśnie, nade wszystko, miały prowadzić do bezrobocia i ubóstwa. Majętność traktowano także w dużej mierze jako oznakę religijności i pobożności. Akcentowano starotestamentowe przekonanie, że Bóg błogosławi, również materialnie, ludzi pobożnych, oddanych $\mathrm{Mu}$ i postępujących zgodnie z biblijnymi nakazami etycznymi. Przekonanie to wzmacniano nie tylko kalwińską (jednostkową) ideą predestynacji, ale i podkreślaniem, że purytanie są nowym ludem wybranym przez Boga, cieszącym się z tej racji nowymi przywilejami i szczególnym błogosławieństwem, także materialnym, niekoniecznie dostępnym dla innych (chyba że ci zostaną podniesieni z upadku moralnego $)^{65}$.

Uczestnicy ruchu oksfordzkiego, będącego pod wieloma względami ruchem krytycznym wobec protestantyzmu i wyrastającego na jego bazie indywidualizmu, odrzucali nie tylko purytańsko-liberalne przekonanie o uprzywilejowaniu pewnej grupy ludzi przez Boga i jego konsekwencjach, ale też o związku między ubóstwem a upadkiem moralnym człowieka. Ich obiekcje budził nie tyle sam związek cnoty z bogactwem (która, przyznawali pośrednio, mogła do niego prowadzić), ile wszelkie sugestie, że bogactwo wynika jedynie z cnoty, a ubóstwo jedynie z upadku. Bardzo krytycznie zapatrywali się więc na to, że ubóstwo traktuje sie jak grzech albo trąd, chce sie je odsytać do więzienia lub lazaretu ${ }^{66} \mathrm{i}$ że na bogactwo patrzy się jak na cnotę, karzac jednocześnie ubóstwo jako zbrodnię ${ }^{67}$. Twierdzili, że sytuacja, w której alkoholizm wpędza ludzi w ubóstwo, jest faktycznie znacznie rzadsza od relacji odwrotnej, w której to ubóstwo wpędza w alkoholizm ${ }^{68}$. Wskazywali przez to, że przyczyną ubóstwa mogą być i bywają „warunki społeczne” oraz że wady są raczej konsekwencją niż przyczyną ubóstwa. Sugerowali,

red. N. Phillipson, Q. Skinner, Cambridge 1993. Chociaż inne były uzasadnienia dążeń wigów (racje ekonomiczne) i purytanów (prawdy biblijne), to jednak wiele z nich pokrywało się, zwłaszcza tych ze sfery ekonomicznej i politycznej. Wigowie, podobnie jak purytanie, bronili interesów klasy średniej, której naturalnym dążeniem był rozwój handlu i rzemiosła. Oba ugrupowania akcentowały wolność jednostki, jej samodzielność, przedsiębiorczość i odpowiedzialność za własny los. Wigowie, jak i purytanie, pozostawali zdeklarowanymi przeciwnikami monarchii absolutnej, opowiadającymi się za silną pozycją angielskiego parlamentu. Wreszcie oba nurty przeciwne były silnej pozycji państwowego Kościoła, jego związku z państwem, Kościołowi hierarchicznemu i mocnej pozycji społecznej duchowieństwa (P. Musiewicz, Purytańska etyka pracy..., s. 77).

65 M. Weber, The Protestant Ethic and the Spirit of Capitalism, London 1950, s. 2-7, 35-36, 166, 172; A. McGrath, Kalwin a powotanie chrześcijańskie, [w:] Cztowiek z Noyon. O Janie Kalwinie na tamach „Jednoty”, red. E. Jóźwiak, K. Urban, Warszawa 2009, s. 122; M. Księżopolski, Polityka spoteczna..., s. 20; P. Jaskóła, Predestynacja - kontrowersyjna idea Kalwina, [w:] W nurcie myśli Jana Kalwina, red. J. Budniak, P. Jaskóła, R. Porada, Opole 2009, s. 42.

66 T. Mozley, Pews, s. 494.

67 F.E. Paget, The Pageant, s. 189.

68 S. Bosanquet, Pauperism and Alms-giving, s. 213. 
że brak dostrzegania tych faktów, akcentowanie osobistej odpowiedzialności za ubóstwo i prześladowanie żebraków ma u swojej przyczyny samolubne rozumowanie, pragnienie ochrony życia w luksusie i traktowania innych z pogardą oraz ochronę przed karą tych, którzy są w istocie sprawcami biedy innych (zamożnych wykorzystujących na różne sposoby ubogich) ${ }^{69}$.

Na głębszej płaszczyźnie sprzeciw traktarian wobec indywidualnej odpowiedzialności za ubóstwo brał się z ich akcentu na wspólnotowość, także lokalną. Nie dążyli bowiem, jak liberałowie, do gwarantowania przez państwo praw i wolności jednostkowych, lecz raczej do tego rodzaju gwarancji na płaszczyźnie „kolegialnej”, zwłaszcza wobec Kościoła anglikańskiego i jego jednostek lokalnych - parafii. Zamiast akcentować indywidualną odpowiedzialność ubogich za swój stan, zwracali uwagę na indywidualną i lokalną odpowiedzialność za ubogich, pragnąc nade wszystko, aby lokalne wspólnoty miały swobodę jej realizacji. Krytycznie odnosili się przy tym do ewangelikalnej koncepcji wyłącznie indywidualnej odpowiedzialności za pomoc ubogim, minimalizującej rolę lokalnej wspólnoty - uważali, że takie działania mają w praktyce charakter nazbyt ostentacyjny i rozproszony ${ }^{70}$.

\section{ZAKOŃCZENIE}

Uczestnicy ruchu oksfordzkiego negatywnie odnieśli się do nowego prawa o ubogich. Główne ich zastrzeżenie dotyczyło nadmiernego zaangażowania państwa w organizację i zapewnianie pomocy ubogim, gdyż twierdzili, że sprawami tymi, z racji biblijnych, historycznych, jak i praktycznych, powinien zajmować się Kościól. Pozostawienie tego obowiązku Kościołowi ma umożliwić realizację religijnego obowiązku dawania jałmużny, jest też praktyką znajdowaną zarówno w starożytności chrześcijańskiej, jak i w historii Anglii, praktyką, od której ustawa z 1834 r. usiłuje odejść w sposób rewolucyjny. Wreszcie Kościół lokalny, zwłaszcza parafie, lepiej od urzędów centralnych i dużych jednostek administracyjnych będzie w stanie rozpoznać potrzeby ubogich, skoro ma z nimi bezpośredni kontakt. Lepiej byłby w stanie organizować także domy pracy, nadając im bardziej ludzki charakter, nakierowany faktycznie na polepszenie ich bytu, nie zaś na zniechęcenie do korzystania z pomocy. Traktarianie nie zgadzali się bowiem z wigowskim założeniem, że wyłączną przyczyną ubóstwa jest upadek moralny i że odpowiedzialność za ubóstwo ma charakter czysto indywidualny.

Rozwiązania problemu ubogich skłonni byli poszukiwać nie tyle na drodze czysto legislacyjnej, w której nie pokładali nadziei ${ }^{71}$ (choć na drodze tej pragnęli uznania odpowiedzialności Kościoła za ubogich), ile na drodze pobudzenia hojności członków wspólnoty lokalnej, akcentując szczególnie, choć nie tylko, obowiązki społeczne

\footnotetext{
69 Tenże, Private Alms and Poor-law Relief, s. 449.

70 S.A. Skinner, Tractarians and the 'Condition of England'..., s. 234.

$71 \quad$ Tamże, s. 222.
} 
wynikające z posiadania. Czynili to $\mathrm{w}$ dużej mierze $\mathrm{w}$ kazaniach $^{72} \mathrm{i}$ dając przykłady własnym postępowaniem ${ }^{73}$.

Angielski system opieki nad ubogimi nie został zreformowany w kierunku postulowanym przez uczestników ruchu oksfordzkiego. Jego ewolucja wskazuje nie na zmniejszanie roli państwa i zwiększanie Kościoła, lecz dokładnie przeciwnie. Podstawowy postulat traktarian pozostał więc niezrealizowany ${ }^{74}$. Faktycznemu zwiększeniu roli państwa, wyrażającemu się na przykład w utworzeniu systemu opieki emerytalnej i zdrowotnej, towarzyszyło jednak stopniowe porzucanie przekonania, że ubóstwo jest wyłącznie wynikiem upadku moralnego. W konsekwencji sposób traktowania ubogich stawał się bardziej dostosowany do potrzeb i „osobisty” (jak mogliby powiedzieć traktarianie). Niektóre, inne niż podstawowe, postulaty uczestników ruchu oksfordzkiego dotyczące sposobu traktowania ubogich z czasem zostały więc spełnione, choć trudno stwierdzić, żeby ruch ten miał na ich uchwalenie decydujący wpływ.

Refleksję uczestników ruchu nad sposobem pomocy ubogim można też odczytywać jako próby tworzenia „anglikańskiej nauki społecznej”. Traktarianie, wpisujący się w Kościele anglikańskim do stronnictwa wysokokościelnego, stanowili co prawda zaledwie jedno z wielu środowisk tegoż Kościoła (w dodatku środowisko pozostające w ostrej polemice zwłaszcza ze stronnictwem niskokościelnym i latytudynarnym), jednakże uprawiali swoją refleksję z przekonaniem, jakby odkrywała ona na nowo „katolicką” istotę Kościoła anglikańskiego, mającego - z racji posiadania episkopatu - stanowić jedną z gałęzi Kościoła Chrystusowego $^{75}$. Odchodząc od protestanckiego indywidualizmu, pragnęli jaśniejszej artykulacji zasad wiary i postępowania, w tym zasad społecznych, które wiązałaby wszystkich członków tegoż Kościoła - temu też służyć miała ich refleksja. Ponieważ jednak Kościół anglikański, podobnie jak państwo, podążył w innym kierunku, niż postulowali uczestnicy ruchu, i nie zaakcentował w wyraźny sposób dziedzictwa katolickiego i wspólnych zasad, jednolita dla tego Kościoła „anglikańska nauka społeczna” nie mogła się rozwinąc ${ }^{76}$.

72 Dawajmy to, co będzie nas kosztować i z czego nietatwo będzie rezygnować. Zgódźmy się, aby rozstać się z pewnym luksusem, aby zostawić w rękach Boga to, w zdobycie czego wtożyliśmy wiele wysitku. Dawajmy ponad miare, nie tylko wedle tego, co leży w zasiegu naszych możliwości. Jeżeli przekazanie jednego lub dwóch funtów nic nas nie kosztuje, przekazujemy pięć, dziesięć, dwadzieścia, pięćdziesiąt. Zacheusz rozdat ubogim potowe swoich dóbr (F. Oakeley, The Dignity and Claims of the Christian Poor. Two Sermons, London 1840, s. 36).

73 Pusey samodzielnie ufundował kościół St. Savior w Leeds i był stałym, hojnym dawcą na fundusz budowy kościołów; aby móc przekazywać więcej ubogim, zrezygnował ze wspólnych obiadów profesorskich w Oksfordzie i sprzedał własną dorożkę, a jego żona całą biżuterię. Sam głosił: Czyż nie bytoby btogostawieństwem, gdyby kobiety oddaty swe ozdoby [...] z uwagi na stużbę Bogu? Czyż nie ma btogostawieństwa w tym, kiedy luksusy, przepych, zaprzegi, wyposażenie, drogie naczynia umieszcza się w skarbcu Boga? Wówczas bogaty, który tam je odda, może chodzić po ulicach miasta, które jest ze szczerego ztota (E.B. Pusey, Parochial Sermons..., s. 386-387).

74 P. Musiewicz, Ruch oksfordzki (1833-1845)..., s. 189-190.

75 Zob. J.W. Bowden, A Short Address to His Brethern in Christ on the Nature and Constitution of the Church of Christ, and of the Branch of it Established in England, [w:] Tracts for the times, vol. 1: Tract 5, red. J.H. Newman, Oxford 1834, s. 1-14.

76 Warto zauważyć pewne podobieństwo (domagające się zapewne odrębnych badań) nakreślonych anglikańskich propozycji społecznych ruchu oksfordzkiego do formułowanej później katolickiej nauki 


\section{BIBLIOGRAFIA}

Teksty źródłowe - pisma ruchu oksfordzkiego:

Bosanquet S., The Age of Unbelief, „British Critic” 1842, vol. 31, nr 61.

Bosanquet S., Pauperism and Alms-giving, ,British Critic” 1840, vol. 28, nr 55.

Bosanquet S., Private Alms and Poor-law Relief, „British Critic” 1840, vol. 28, $\mathrm{nr} 56$.

Bowden J.W., A Short Address to His Brethern in Christ on the Nature and Constitution of the Church of Christ, and of the Branch of it Established in England, [w:] Tracts for the Times, vol. 1: Tract 5, red. J.H. Newman, Oxford 1834.

Froude R.H., Remains of the Late Reverend Richard Hurrell Froude, vol. 3, red. J.H. Newman, J. Keble, J.B. Mozley, London 1839.

A Collection of Papers Connected with the Theological Movement of 1833, red. A.P. Perceval, London 1842.

Gresley W., Acceptable Sacrifice. A Sermon Preached in St.John's Church, Cheltenham, LondonCheltenham 1843.

Gresley W., Anglo-Catholicism, A Short Treatise on the Theory of the English Church, London 1844.

Hooker R., The Works of that Learned and Judicious Divine, Mr. Richard Hooer. With an Account of His Life and Death by Isaac Walton, vol. 1, red. J. Keble, New York 1845.

Keble J., Church and State, [w:] J. Keble, Sermons Academical and Occasional, Oxford 1848.

Keble J., National Apostasy Considered. In a Sermon Preached in St. Mary, Oxford, before His Majesty's Judges of Assize, on Sunday, July 14, 1833, Oxford 1833.

Keble J., The State in its Relations with the Church, Oxford 1869 (przedruk z „British Critic” 1839, vol. 26).

Liddon H.P., Life of Edward Bouverie Pusey, t. 2, London 1894.

Mozley T., Armed Associations for the Protection of Life and Property, „British Critic” 1839, vol. 26, nr 52.

Mozley T., Pews, „British Critic” 1842, vol. 32, nr 64.

Mozley T., Reminiscenses, Chiefly of Oriel College and the Oxford Movement, vol. 2, London 1882.

Newman J.H., Apologia pro vita sua, London 1903.

Newman J.H., Convocation of Canterbury, [w:] J.H. Newman, Historical Sketches, vol. 3, London 1909.

Oakeley F., Remarks on the Study of Aristotelian and Platonic Ethics, as a Branch of the Oxford System of Education, Oxford-London 1837.

Oakeley F., The Dignity and Claims of the Christian Poor. Two Sermons, London 1840.

Paget F.E., Milford Malvoism or Pews and Pewholders, London 1842.

Paget F.E., The Pageant, London 1843.

społecznej, na przykład do ostrzeżeń Jana Pawła II, aby dobro jednostki nie zostało podporządkowane działaniu mechanizmu ekonomiczno-społecznego (Centesimus annus, 13), do akcentowania przez niego, a wcześniej m.in. Leona XIII, społecznej roli wspólnot innych niż państwo („grup pośrednich”), które winny posiadać własną autonomię (CE 13, Rerum novarum, 28, 42), do sformułowanej przez Piusa XI zasady pomocniczości (Quadragesimo anno, 80-81), czy też do zasady społecznej solidarności (Solicitudo rei socialis, 38). 
Paget F.E., Warden of Berkingholt, Oxford 1843.

Pusey E.B., Christianity without the Cross a Corruption of the Gospel of Christ. A Sermon Preached before the University of Oxford on Septuagesima Sunday, Oxford-London 1875.

Pusey E.B., Patience and Confidence the Strength if the Church. A Sermon Preached on the Fifth of November before the University of Oxford at S. Mary's, Oxford 1841.

Pusey E.B., The Royal Supremacy. Not an Arbitrary Authority but Limited by the Laws of the Church of which Kings are Members, Oxford 1850.

Ward W.G., The Ideal of a Christian Church, London 1844.

Inne teksty źródłowe i opracowania:

Belchem J., Industrialization and the Working Class. The English Experience, 1750-1900, Aldershot 1990.

Biblia Tysiąclecia, Poznań 2003.

Blease W.L., A Short History of English Liberalism, London 1913.

Bloy M., The Settlement Act, [online] http://www.victorianweb.org./history/poorlaw/settle. html.

Bloy M., The 'workhouse test Act', [online] http://www.victorianweb.org/history/poorlaw/tes tact.html.

Cross A.L., A Shorter History of England and Great Britiain, New York 1920.

Dawson Ch., The Spirit of the Oxford Movement, London 2011.

Driver C., Tory Radical. The Life of Richard Oastler, Oxford 1946.

Driver F., Power and Pauperism. The Workhouse System, 1834-1884, Cambridge 1993.

Edsall N.C., The Anti-Poor Law Movement, 1834-44, Manchester 1971.

Garbat M., Pauperyzacja i powstanie polityki spotecznej na przyktadzie Anglii w epoce elżbietańskiej, „Nierówności Społeczne a Wzrost Gospodarczy” 2013, z. 34.

Gill J.C., Parson Bull of Byerley. A biography of George Stringer Bull, London 1963.

Goldie M., Priestcraft and the birth of Whiggism, [w:] Political Discourse in Early Modern Britain, red. N. Phillipson, Q. Skinner, Cambridge 1993.

Griffin J.R., John Keble: Radical, „Anglican Theological Review” 1971, vol. 53.

Ker I., John Henry Newman, Oxford 2009.

Kędzierski J.Z., Dzieje Anglii 1485-1939, t. 1, Wrocław 1986.

Llewellyn A., The Decade of Reform. The 1830s, Exeter 1972.

Jan Paweł II, Centesimus annus, 1991.

Jan Paweł II, Solicitudo rei socialis, 1987.

Jaskóła P., Predestynacja - kontrowersyjna idea Kalwina, [w:] Wnurcie myśli Jana Kalwina, red. J. Budniak, P. Jaskóła, R. Porada, Opole 2009.

Knott J., Popular Opposition to the 1834 Poor Law, London 1986.

Księżopolski M., Polityka spoteczna. Wybrane problemy porównań międzynarodowych, Katowice 1999.

Laski H.J., Studies in the Problem of Sovereignty, New Haven 1913.

Leon XII, Rerum novarum, 1891.

McCord N., The Poor Law and Philanthropy, [w:] The New Poor Law in the Nineteenth Century, red. D. Fraser, London 1976. 
McGrath A., Kalwin a powotanie chrześcijańskie, [w:] Cztowiek z Noyon. O Janie Kalwinie na tamach „Jednoty”, red. E. Jóźwiak, K. Urban, Warszawa 2009.

Musiewicz P., Krótka historia ruchu oksfordzkiego (1833-1845). O kontrowersjach traktariańskich oraz ich kontekście historycznym i religijnym, „Politeja” 2011, nr 1 (15).

Musiewicz P., Ruch oksfordzki (1833-1845). Myśl polityczna przywódców ruchu oksfordzkiego, Kraków 2015.

Musiewicz P., Purytańska etyka pracy a ewolucja angielskiej polityki spotecznej, [w:] Wychowanie i praca. W trosce o integralny rozwój cztowieka, red. Z. Marek, J. Mółka, M. Mółka, Kraków 2017.

Musiewicz P., The Oxford Movement's Arguments for the Union of Church and State, „Horyzonty Polityki”, 2014, vol. 5, nr 13.

Newland H., Three Lectures on Tractarianism, London 1852.

Norman E.R., Church and Society in England 1770-1970. A Historical Study, Oxford 1976.

O ruchu religijnym $w$ Anglii, „Przegląd Poznański” 1845, t. 2.

Overton J.H., The Anglican Revival, London 1897.

Pius XI, Quadragesimo anno.

Pratt A., Subsydiowanie ptac, polityka spoteczna i państwo. Od prawa o ubogich do polityki „nowej" partii pracy, [w:] Polityka spoteczna. Teorie, pojęcia problemy, red. M. Lavalette, A. Pratt, przeł. P. Jaworski, Warszawa 2010.

Pusey E.B., Parochial Sermons, 1848-1883, vol. 3, Oxford-London 1886.

Scharf T., Polityka spoteczna w Wielkiej Brytanii. Od ustawy o ubogich do „trzeciej drogi”, [w:] Państwo socjalne w Europie. Historia - Rozwój - Perspektywy, red. K. Kraus, T. Geisen, K. Piątek, przeł. M. Bratkowska-Zariczna, P. Zariczny, Torun 2005.

Skinner S.A., Tractarians and the 'Condition of England'. The Social and the Political Thought of the Oxford Movement, Oxford 2004.

Szlachta B., Konserwatyzm, [w:] Doktryny polityczne XIX i XX wieku, red. W. Kozub-Ciembroniewicz, K. Chojnicka, Kraków 2000.

Trevelyan G.M., Historia Anglii, przeł. A. Dębnicki, Warszawa 1963.

Ward J.T., The Factory Movement 1830-1855, London 1962.

Weber M., The Protestant Ethic and the Spirit of Capitalism, London 1950.

Zins H., Historia Anglii, Wrocław-Warszawa-Kraków-Gdańsk 1979.

Piotr MUSIEWICZ - dr nauk społecznych w zakresie nauk o polityce (WSMiP UJ), mgr politologii (INPiSM UJ), adiunkt w Instytucie Nauk o Polityce i Administracji Akademii Ignatianum w Krakowie. Prowadzi badania w tematach relacji państwo Kościół, historii myśli politycznej (głównie angielskiej) i polityki publicznej (zwłaszcza polityki społecznej). 